\title{
Divisional Reading Rooms in the Small Liberal Arts College
}

Jean M. Sharpe is librarian of the Rockford College Library, Rockford, Illinois.

$\mathrm{T}$ RADITION has decreed for college and university libraries a conventional plan which emphasizes the large central reading room. If of late there has been some questioning, uncertainty, and even uneasiness with this emphasis, we must look for guidance, not only in the statements of our own profession but at the shift in educational methods and procedures which are compelling the library to assume a more important place in the educational scheme. When the professor lectured and the student read a textbook, the library had its appointed place in the educational organization, but it was not one of first importance. More recently with the introduction of honors and independent reading courses, tutorial systems, and the stressing of the advantages of the small class, the education of the student has become a more individualized process which centers around teaching with books.

As these new directions become apparent, librarians are discussing the type of library building best suited to fit in with these methods. They are studying the library from the standpoint of "educational effectiveness rather than its administrative efficiency." 1 The large reading

'Branscomb, Harvie. Teaching with Books: $A$ Study of College Libraries. Association of American Colleges and A.L.A., 1940, p. ix. room as opposed to small subject or divisional reading rooms is, of course, only one phase in the discussion. The size and type of the student body and the character of the teaching of the institution are determining factors in the conception of the building, and the problem is one which must be solved independently by each library.

Thus, in the new library at Rockford College, serving a community of 300 students and 45 faculty members, we have chosen to omit the large reading room and to center our plan around the idea of divisional reading rooms. The general type of teaching to which this library contributes is best described in an editorial introduction by Professor Carl Becker:

Teaching and learning are most effectively conjoined when an alert and informed teacher engages in informal discussion with a small group of alert and informed students. If the subject be history, the students will on their own initiative and with mounting enthusiasm (it is an ideal we are describing) spend much of their time in the library, where they will be provided with tables and the necessary books for an independent study of the subject. Once or twice a week the professor will meet his pupils. In so small a group he may dispense with lectures-those exercises in which students assemble, and amiably and passively sit while the professor, with great advantage to himself, clarifies his ideas by oral discourse. The students also will have an opportunity to clarify their ideas by oral dis- 
course. Teaching and learning will then be conjoined, as they always must be to be any way effective: professor and pupils, each according to his talent, will be both teachers and learners. ...'

This is not merely "ideal"; it is the kind of teaching Rockford College seeks to offer and with which the library must be closely integrated.

\section{Accessibility of Books}

The first requisite for independent study (we assume a well-selected book collection) is the accessibility of books. This is possible when everything is open to the whole student body, stacks, reserves, art collection, periodicals, and these materials arranged to be used most effectively.

At Rockford the four divisional reading rooms following the general plan of the curriculum are devoted to humanities, social sciences, arts, and science. This is in no sense a radical departure from what we had already been doing. The old library on the third floor of Middle Hall consisted of twelve rooms which were in reality subject reading rooms. This arrangement was not planned but developed as an expanding library took over room after room. The reserves were open and placed near books in the same field, thus breaking down some of the artificiality of the reserve shelf. There was a charm in the old uneven lines, the individual study nooks, and the general atmosphere of informality. To quote from Randall and Goodrich :

Many students seem to prefer to study in a rather small informal room. They choose such a room in preference to an imposing reading room. If it were possible to afford the necessary staff, a departmental system

${ }^{2}$ Ferguson, Wallace K., and Bruun, Geoffrey. $A$ Survey of European Civilization. Under the editorial supervision of Carl L. Becker. Houghton, Mifflin, 1936, p. vii. of reading rooms, similar to the Cleveland and Los Angeles public library plans, would fit into the present trend in instruction....

In our situation the "necessary staff" was not available but its function was fulfilled in some measure by the faculty, in courses and in conferences, giving bibliographical training, and by the creation in the student body of a feeling of responsibility which made the use of small unsupervised subject rooms possible. With a circulation of over thirty-five thousand books last year there was a loss of only four.

\section{Grouping of Subjects That Belong To- gether}

In the new building it seemed wiser to have in place of many subject divisions a grouping of those subjects which naturally belong together and to place in the preferred position on the first floor the humanities and social sciences, subjects for which the library serves as a book laboratory, and on the second floor the arts and sciences which have their own studios and laboratories elsewhere on the campus. The reading rooms are divided by alcoves to preserve the feeling of the small room and to keep in so far as possible the direct and natural approach to books. The books and materials which are essential to these several fields have been placed in the reading rooms: information files, periodicals, reference books and bibliographies, and reserves. We are also working on a "core collection" for each room which will be selected by the faculty of each division in cooperation with the librarian.

In the central position on the first floor the circulation desk has been placed, and near by, the general catalog where every search for information begins. Here also

${ }^{3}$ Randall, William M., and Goodrich, Francis L. D. Principles of College Library Administration. A.L.A. and the University of Chicago Press [c1936], p. 171. 
is space for exhibits, bulletin boards, and displays of new books. In the rare book room on the second floor the treasures of the library have been housed and will be placed frequently on exhibit.

Conference or study rooms are adjacent to the reading rooms. While no classes will be scheduled regularly in the library, small groups can, of course, at any time reserve one of these conference rooms when the instructor wishes to conduct the class near the books, but primarily they are what they have been termed, "conference rooms." The divisional rooms will also be available at certain times (perhaps between four and six when the attendance in the library is usually very light) for an occasional meeting of a larger class. In the old library this type of use was most successful.

Conveniently located in relation to the reading rooms are the stacks, four tiers in height, where materials of perhaps less immediate importance are kept. The carrels for students doing honors work or special projects are ranged on two sides of the stack levels. The student typing room, the staff room, the work space, as well as three of the conference rooms are also in the stacks.

\section{A Friendly, Informal Air}

The furniture is in keeping with the simple and direct lines of the Georgian building. Fireplaces in three of the reading rooms add to the friendly, informal air of the library and around them have been grouped comfortable chairs and occasional tables. In all the furniture enough variation has been presented to avoid the institutional appearance. Single study desks, for instance, have been placed near the wide windows which look out over the river or across the north campus. There is no special room for leisure reading. This seemed unnecessary not only because of the general informality of the entire library but because the book program of the college has always stressed the dormitory library for recreational reading and the browsing feature of the bookshop at Maddox House where the emphasis is on reading rather than on sales.

To administer this new library with a small staff will be quite definitely an experiment and will call for the closest kind of faculty and student cooperation. The aim will be to carry into the new and more formal building as much of the informality of the old as possible. By informality we mean the complete openness of everything, the simplified charging system, the privilege of all students to take out an unlimited number of books, the absence of a time limit (the books are checked three times a year), the open reserves, and the very liberal hours during which the library may be used.

Experimental as the Rockford College Library is in some of its features, we believe it fits the needs of our particular college. In its new and more spacious setting we hope it will continue to do with even more effect that which it has done for many years-to make accessible and as attractive as possible to the student the precious volumes which comprise her intellectual and spiritual inheritance, the acquaintance with which will guide and direct her in that difficult and eternal pursuit of significant and elusive truth. 